\title{
The effect of central bank transparency on inflation persistence
}

\author{
Georgios Oikonomou ${ }^{1} \bullet$ Stephanos Papadamou $^{2, *} \cdot$ Eleftherios Spyromitros $^{1}$ \\ ${ }^{1}$ Democritus University of Thrace, Department of Economics, Komotini, Greece \\ ${ }^{2}$ University of Thessaly, Department of Economics, Volos, Greece
}

Received: 16 August 2019

Revised: 5 June 2020

Accepted: 16 June 2020

\begin{abstract}
In this paper, we examine the effect of central bank transparency on inflation persistence, using panel data analysis. The existing literature has shown a significant impact of central bank transparency on macroeconomic variables, such as inflation, but not many efforts have been made about its effect on inflation persistence. We use yearly data for 14 countries and the Eurozone (EU19). We find that monetary policy transparency has a negative statistically significant impact on inflation persistence, while controlling also for important variables such as GDP growth, interest rates, economic openness and unit labor cost.
\end{abstract}

Keywords: monetary policy; central bank transparency; inflation persistence; panel data JEL Classification Codes: E52, E58

\section{Introduction}

Historically, the issue of inflation persistence attracted the attention of the international literature for many decades, with researchers focusing both on the effects and the causes of this phenomenon. Many researchers (Taylor, 1980; Calvo, 1983; Fuhrer and Moore, 1995; Calvo et al., 2002; Christiano et al., 2005; Blanchard and Gali, 2007) showed that the phenomenon is a structural feature by focusing on price and wage stickiness, and indexation or staggered wage contracts. Another strand of the literature (Huh and Lansing, 2000; Andolfatto and Gomme, 2003 and Erceg and Levin, 2003) argue that in the case of imperfect transparency and credibility, there is a learning process from the public that generates additional inflation persistence. In the same spirit, Westelius (2005) has shown that a discretionary monetary policy does not succeed in incorporate the impact of credibility and transparency on inflation expectations, generating thus a considerable amount of persistence in inflation. Ball (1995) explained inflation

\footnotetext{
*Corresponding author. E-mail: stpapada@uth.gr.

Citation: Oikonomou, G., Papadamou, S., and Spyromitros, E. (2021) The effect of central bank transparency on inflation persistence, Economics and Business Letters, 10(1), 58-68.
}

DOI: 10.17811/ebl.10.1.2021.58-68 
fluctuations regarding tougher or looser monetary policies, where the latter is more likely to produce more persistent inflation. Baxa et al. (2015) suggest that inflation targeting policies reduce inflation persistence ${ }^{1}$. To the same extend, Canarella and Miller (2016), after analyzing data from 13 inflation targeting countries found that these policies reduce inflation persistence and raise monetary policy credibility. Kočenda and Varga (2018) focusing on inflation targeting policies, show that explicit policies reach better results in controlling inflation persistence, than implicit inflation targeting policies $\mathrm{do}^{2}$. Moreover, regarding the effects of labour market, Jaumotte and Morsy (2012) and Geronikolaou et al. (2016) suggested that labour markets rigidities are responsible for higher and more persistent inflation.

Little attention has been given so far to the link between central bank characteristics and inflation persistence. However, central bank independence and transparency proved to be important elements for the efficiency of monetary policy and therefore their performance in terms of inflation and inflation variability (see, among others, Alesina and Summers, 1993; Eijffinger et al., 2000; Geraats, 2005; Hughes Hallett and Libich, 2006; Crowe and Meade, 2007; Demertzis and Hughes-Hallett, 2007; de Mendonça and Galveas, 2013; Dincer and Eichengreen, 2014; Papadamou and Arvanitis, 2015; Montes and Gea, 2018, Weber, 2018). However, there are also some theoretical studies which show that the effects of central bank transparency may also be negative (Sørensen, 1991; Gruner, 2002; Sibert, 2002; Westelius, 2009) ${ }^{3}$.

Focusing thus on the effects of central banks' independence on inflation persistence, findings by Diana and Sidiropoulos (2004) suggest that more independent central banks are associated with lower degrees of inflation persistence. In the same way, Papadamou et al. (2017) suggest that an independent central banker could better manage inflation expectations and therefore inflation persistence despite the occurrence of persistent public investment shocks.

Considering the effects of central banks' transparency on inflation persistence, Van der Cruijsen and Demertzis (2007) argue that there is a negative link between central bank transparency and inflation persistence using a dataset of nine OECD countries. Dincer and Eichengreen (2007), using a much larger set of countries, have shown that central bank transparency negatively affects inflation persistence ${ }^{4}$. These results are consistent with the view that higher levels of monetary policy transparency allow the public to adjust their expectations more quickly, limiting thus policymakers' willingness to run persistently inflationary policies. However, Van der Cruijsen et al. (2010) suggest that there is an optimal intermediate degree of transparency that minimizes inflation persistence.

This paper is one of the few studies that empirically investigate the effects of central banks' transparency on inflation persistence, providing also an update of the time period of investigation and including some neglected, although relevant, control variables. Using data from 14 OECD countries plus EU19 (regarding ECB's transparency) over the period 2002-2016 and applying a panel data approach, we show that transparency reduces inflation persistence.

The paper is structured as follows. Section 2 presents the data and the basic model. Section 3 analyzes the relationship between inflation persistence and central banks' transparency, GDP growth and interest rates. Section 4 concludes.

\footnotetext{
${ }^{1}$ Alogoskoufis (2018) considered that monetary policy rules targeting unanticipated changes in unemployment rates, could improve results in terms of inflation persistence.

${ }^{2}$ For more studies on monetary policy orientation effects on inflation persistence, see, among others, Taylor (2000), Goodfriend and King, (2001), Conrad and Eife, (2012), Meller and Nautz, (2012), Qin et al. (2013), and Noriega et al. (2013).

${ }^{3}$ It is to notice that according to Cukierman (2002), if a central banker does not publish its economic models and objectives, it is more likely to have higher levels of credibility.

${ }^{4}$ It is to mention that Dincer and Eichengreen (2010) did not find a statistically significant effect for this relationship.
} 


\section{Data and methodology}

In this paper we use data for 14 countries, all of them being OECD members (Australia, Canada, Croatia, Denmark, Hungary, Iceland, Israel, Mexico, New Zealand, Norway, South Korea, Sweden, Switzerland, United Kingdom) and the Euro-zone (EU19) member countries, in order to test also the ECB's inflation persistence and transparency. The time period used is from 2002 to 2016.

Transparency (TRNS) is taken from Dincer and Eichengreen (2014) for the time period of 2002-2010 and for the time period 2011-2016 we use data from Oikonomou and Spyromitros (2017), as both of them use the same methodology of calculation developed by Eijffinger and Geraats (2006) $)^{5}$. According to Fuhrer (2010), there is no universally accepted method of calculating inflation persistence. Summarising the methods, we have the conventional unit root tests, the autocorrelation function of the inflation series, the first autocorrelation of the inflation series, the dominant root of the univariate autoregressive inflation, the sum of autoregressive coefficients and the unobserved components decomposition of inflation ${ }^{6,7}$. In our analysis inflation persistence is calculated using the functional form:

$$
\text { persistence }=\rho=\frac{\operatorname{Cov}\left(\pi_{t}, \pi_{t-1}\right)}{\operatorname{Var}\left(\pi_{t}\right)}
$$

where $\rho$ is the correlation coefficient between $\pi_{t}$ and $\pi_{t-1}$, where $\pi_{t}$ is the annual inflation rate at year $t$. We apply a rolling window approach of 10 years, where for each year we consider the previous ten- year inflation rates $^{8}$. For inflation persistence (INFp), we use inflation data from OECD database. Interest rates (IR) are taken from the OECD database and concern the annual money market interest rates for each country. In case of European countries, we use the annual EURIBOR rate, taken from the EURIBOR website and in the case of United Kingdom we apply the annual LIBOR rate, taken from the LIBOR website. For GDP growth rate (GDPg), we use the OECD database. The trade openness (OPN) of each country is measured as the percentage of the total trade over GDP. Unit labour costs (ULC) is our final control variable, in order to measure the effect of the labour market on inflation persistence. Finally, we apply a European union country dummy variable (EUDUMMY) in order to capture the effect of being a member of the European union on inflation persistence, which in case of European union is equal to 1, otherwise 0 (descriptive statistics for all countries and variables are presented in Table 1$)^{9}$. Mexico, UK and Iceland are found with the highest inflation persistence mean, while Australia has the lowest. Regarding central bank transparency, Sweden and New Zealand have the highest mean, while the lowest means are Mexico's and Denmark's.

\footnotetext{
${ }^{5}$ Another index of transparency is the one developed by Fry et al. 2000.

${ }^{6}$ It is to notice that several authors use multivariate models to calculate the response of inflation to various disturbances (Batini and Nelson, 2001; Batini, 2002). Another alternative method considers that if inflation is not very persistent, it should cross its mean relatively frequently and measures the measures of these incidents (Marques, 2004; Dias and Marques, 2010).

${ }^{7}$ For a discussion on the advantaged and disadvantages of several methods of persistence calculation see Marques (2004) in the context of the univariate approach.

${ }^{8}$ See among the others Geronikolaou et al. (2019).

${ }^{9}$ The variables we apply in our model are widely used as controls for inflation persistence. As for the effect of GDP growth on inflation persistence the sign is expected to be positive (as in Geronikolaou et al., 2019). Concerning the effect of Interest Rates, the sign is expected to be negative (see among the others Alogoskoufis, 1992; Taylor, 2000; Bratsiotis et al., 2015). Trade openness and inflation are expected to be negatively correlated (Romer, 1993; Lane, 1997). Unit labour costs as a proxy for price competitiveness is expected to have a positive sign (Van der Cruijsen et al., 2010). Finally, the European Union dummy is expected to have ambiguous effect on inflation persistence, depending on the structural characteristics over the economies, as well as the economic policies applied in the economies in our sample.
} 
Table 1. Descriptive Statistics.

\begin{tabular}{|c|c|c|c|c|c|c|c|}
\hline $\begin{array}{l}\text { Variable / } \\
\text { Country }\end{array}$ & & $I N F p$ & $\begin{array}{r}\text { TRNS } \\
(\min .0 \\
\max .15)\end{array}$ & GDPg & $I R$ & $O P N$ & $U L C$ \\
\hline \multirow[t]{2}{*}{ Australia } & Mean & 0.093607 & 10.05263 & 5.242307 & 4.625307 & 40.88947 & 87.79727 \\
\hline & St. Dev & 0.419355 & 1.649029 & 2.421824 & 1.456992 & 1.853793 & 12.98885 \\
\hline \multirow[t]{2}{*}{ Canada } & Mean & 0.135825 & 11.63158 & 4.169545 & 2.647923 & 68.7 & 93.80543 \\
\hline & St. Dev & 0.254217 & 1.352386 & 2.622089 & 1.697962 & 7.223496 & 10.82732 \\
\hline \multirow[t]{2}{*}{ Denmark } & Mean & 0.209836 & 7 & 4.101758 & 2.453515 & 92.06316 & 91.39726 \\
\hline & St. Dev & 0.349166 & 1.092906 & 2.755152 & 1.605402 & 10.95781 & 10.49293 \\
\hline \multirow[t]{2}{*}{ EU19 } & Mean & 0.23383 & 10.71053 & 3.87668 & 2.397895 & 74.24211 & 94.41398 \\
\hline & St. Dev & 0.41539 & 1.228321 & 2.236187 & 1.556505 & 7.939655 & 8.077965 \\
\hline \multirow[t]{2}{*}{ Hungary } & Mean & 0.516574 & 10.89474 & 5.184218 & 5.111982 & 144.5474 & 88.51721 \\
\hline & St. Dev & 0.392437 & 3.860696 & 2.985408 & 5.385875 & 21.93775 & 17.66838 \\
\hline \multirow[t]{2}{*}{ Iceland } & Mean & 0.598433 & 9.394737 & 4.669444 & 8.670527 & 84.16316 & 89.82187 \\
\hline & St. Dev & 0.377672 & 2.850823 & 4.234015 & 3.324697 & 13.48597 & 25.72941 \\
\hline \multirow[t]{2}{*}{ Israel } & Mean & 0.410732 & 9.736842 & 5.109891 & 4.430885 & 69.72632 & 97.7222 \\
\hline & St. Dev & 0.345666 & 1.873562 & 3.904975 & 3.696676 & 7.616637 & 7.526801 \\
\hline \multirow[t]{2}{*}{ Мexico } & Mean & 0.652247 & 6.342105 & 4.963373 & 9.223948 & 58.53684 & 81.52017 \\
\hline & St. Dev & 0.514794 & 1.624916 & 3.165078 & 6.806284 & 8.098574 & 19.747 \\
\hline New & Mean & 0.154312 & 13.68421 & 5.097353 & 5.04386 & 58.96316 & 89.29085 \\
\hline Zealand & St. Dev & 0.272218 & 0.836835 & 2.388005 & 2.078556 & 4.178146 & 11.51059 \\
\hline \multirow[t]{2}{*}{ Norway } & Mean & -0.02429 & 8.736842 & 5.07375 & 3.772532 & 70.03158 & 89.02548 \\
\hline & St. Dev & 0.364983 & 2.694482 & 7.573048 & 2.162239 & 2.63756 & 20.32323 \\
\hline \multirow[t]{2}{*}{ S. Korea } & Mean & -0.00709 & 9.052632 & 5.342544 & 4.558364 & 81.57895 & 97.82247 \\
\hline & St. Dev & 0.278112 & 1.489731 & 4.032507 & 3.012792 & 16.78404 & 6.626727 \\
\hline \multirow[t]{2}{*}{ Sweden } & Mean & 0.307719 & 13.68421 & 4.394735 & 2.449132 & 83.68947 & 95.46353 \\
\hline & St. Dev & 0.31541 & 1.842481 & 3.309228 & 1.600269 & 5.049411 & 10.57079 \\
\hline \multirow[t]{2}{*}{ Switzerland } & Mean & 0.214251 & 9.105263 & 4.694773 & 0.925621 & 101.6421 & 97.87987 \\
\hline & St. Dev & 0.423563 & 1.297208 & 3.055598 & 1.183504 & 25.61519 & 3.690493 \\
\hline \multirow[t]{2}{*}{$U K$} & Mean & 0.608104 & 12.65789 & 3.991466 & 2.788411 & 54.65789 & 90.36475 \\
\hline & St. Dev & 0.335278 & 0.688247 & 2.516158 & 2.077051 & 4.654904 & 11.52174 \\
\hline \multirow[t]{2}{*}{$U S A$} & Mean & 0.221206 & 10.42105 & 4.165062 & 2.362763 & 26.44737 & 128.7557 \\
\hline & St. Dev & 0.303917 & 0.651135 & 2.065334 & 2.245512 & 3.052935 & 11.37043 \\
\hline
\end{tabular}

Our basic empirical model is a panel regressions family mode ${ }^{10}$, estimating a linear equation of the following form:

$$
\begin{gathered}
I N F p_{i t}=\alpha+\beta_{1} \text { TRNS }_{i t}+\beta_{2} I_{i t}+\beta_{3} G_{D P} g_{i t}+\beta_{4} O P N_{i t}+\beta_{5} U L C_{i t}+ \\
\beta_{6} E U D U M M Y_{i t}+\mu_{i}+u_{i t}
\end{gathered}
$$

where the last two terms are the individual heterogeneity term $\left(\mu_{i}\right)$ and the common error term $\left(u_{i t}\right)$. Following Wooldridge (2003), if the individual heterogeneity is correlated with the regressors, the proper specification is the fixed effects regression. When no autocorrelation is assumed, the random effects specification is preferred. The latter represents country level characteristics that are not explicitly included among the independent variables and can therefore cause omitted variable bias.

\footnotetext{
${ }^{10}$ When investigating central bank transparency effects, many researchers use a panel regression family model (see among the others Papadamou et al., 2014). In that extend, and as we find no endogeneity, we proceed in estimating our models, using panel regressions. In case of endogeneity, we would use instrumental variables regression or a Panel GMM model (as in the case of Dincer and Eichengreen, 2010). In this way, we are also differentiated from the autoregressive estimation of Van der Cruijsen et al. (2010).
} 
Table 2. Panel Unit root tests.

\begin{tabular}{lrr}
\hline \hline Variable & $\begin{array}{r}\text { Levin-Lin-Chu } \\
\text { p-value }\end{array}$ & $\begin{array}{r}\text { Im-Pesaran-Shin } \\
\text { p-value }\end{array}$ \\
\hline TRNS & 0.0000 & 0.0305 \\
GDPg & 0.0000 & \\
$I R$ & 0.0000 & 0.0000 \\
OPN & 0.0000 & 0.0000 \\
$I N F p$ & 0.0000 & 0.0000 \\
ULC & N/A & 0.9990 \\
\hline \hline
\end{tabular}

Table 3. Fixed-Effects Regression Results.

\begin{tabular}{|c|c|c|c|}
\hline INFp & (2) & (3) & (4) \\
\hline \multirow[t]{2}{*}{ TRNS } & $-0.093688 * * *$ & $-0.1141346^{* * *}$ & $-0.0871027 * * *$ \\
\hline & $(0.000)$ & $(0.000)$ & $(0.000)$ \\
\hline \multirow[t]{2}{*}{$G D P g$} & 0.0088799 & 0.0078814 & \\
\hline & (0.129) & (0.159) & \\
\hline \multirow[t]{2}{*}{$I R$} & 0.0015785 & -0.0090111 & \\
\hline & $(0.884)$ & (0.284) & \\
\hline \multirow[t]{2}{*}{$O P N$} & -0.0032335 & & \\
\hline & $(0.452)$ & & \\
\hline \multirow[t]{2}{*}{ d.ULC } & $0.0082295 * * *$ & & \\
\hline & $(0.001)$ & & \\
\hline \multirow[t]{2}{*}{ EUDUMMY } & $0.658271 * * *$ & $0.6622488 * * *$ & \\
\hline & $(0.001)$ & $(0.000)$ & \\
\hline \multirow[t]{2}{*}{$\alpha$} & $1.213313 * * *$ & $1.256143 * * *$ & $1.179839 * * *$ \\
\hline & $(0.000)$ & $(0.000)$ & $(0.000)$ \\
\hline \multicolumn{4}{|l|}{ Diagnostics } \\
\hline $\operatorname{Adj} . R^{2}$ & 0.1167 & 0.0996 & 0.0721 \\
\hline \multirow[t]{2}{*}{ Hausman } & $16.33^{\mathrm{a} * *}$ & $73.34^{\mathrm{a} * * *}$ & $8.82^{\mathrm{a} * *}$ \\
\hline & $(0.0121)$ & $(0.0000)$ & $(0.0030)$ \\
\hline \multirow[t]{2}{*}{ Frees Test } & $3.605^{a}$ & $2.984^{\mathrm{a}}$ & $3.036^{\mathrm{a}}$ \\
\hline & $(0.2838)^{\mathrm{b}}$ & $(0.2262)^{b}$ & $(0.2262)^{b}$ \\
\hline \multirow[t]{2}{*}{ Pesaran Test } & $7.270^{\mathrm{a} * * *}$ & $8.369^{\mathrm{a} * * *}$ & $9.353^{\mathrm{a} * * *}$ \\
\hline & $(0.0000)$ & $(0.0000)$ & $(0.0000)$ \\
\hline
\end{tabular}

Notes: $\mathrm{p}$-values in parentheses, ${ }^{\mathrm{a}}$ critical value, ${ }^{\mathrm{b}}$ alpha value, ${ }^{* *}$ and $* * *$ represent significance at $95 \%$ and $99,9 \%$ respectively.

\section{Empirical results}

We first apply unit root tests on all variables of interest (Table 2), where both Im et al. (2003) and Levin et al. (2002) tests conclude in rejecting the null-hypothesis (H0: Panels contain unit roots), except ULC, where there is a unit-root and after first-differencing the variable becomes stationary.

In a second step, we proceed to the estimation of equation (2), and the results are presented in Table 3. It is to notice that we present three different models for robustness checks. Starting from the full model (2), following a model not including variables with a significant effect in the retained results (3) and closing with only transparency as a control variable (4). As can be seen in the lower part of Table 3 by diagnostic tests, the results of the Hausman test for fixed or random effects suggest the fixed effects selection for our basic model. Pesaran (2004) and Frees (1995) tests for cross sectional dependence confirm the existence of dependence of the error terms in our basic model. While, Wooldridge (2003) test demonstrate the appearance of 
Table 4a. Prais-Winsten Regression with Corrected Standard Errors Results.

\begin{tabular}{|c|c|c|c|c|c|c|}
\hline \multirow{2}{*}{$\frac{\text { INFp }}{T R N S}$} & \multicolumn{3}{|c|}{ (4) } & \multicolumn{2}{|c|}{ (3) } & (2) \\
\hline & $\begin{array}{r}-.0344185^{*} \\
(0.053)\end{array}$ & $\begin{array}{r}-.039278^{* *} \\
(0.020)\end{array}$ & $\begin{array}{r}-.033211 * * \\
(0.029)\end{array}$ & $\begin{array}{r}.0332627 * * \\
(0.028)\end{array}$ & $\begin{array}{r}-.0350012^{* *} \\
(0.023)\end{array}$ & $\begin{array}{r}-.0346192 * * \\
(0.021)\end{array}$ \\
\hline$G D P g$ & & & & $\begin{array}{r}-.0016805 \\
(0.643)\end{array}$ & $\begin{array}{r}-.0000703 \\
(0.987)\end{array}$ & $\begin{array}{r}.0002091 \\
(0.960)\end{array}$ \\
\hline$I R$ & . & & $\begin{array}{r}.0136364 \\
(0.208)\end{array}$ & $\begin{array}{r}.0140904 \\
(0.192)\end{array}$ & $\begin{array}{r}.0184186 \\
(0.150)\end{array}$ & $\begin{array}{r}.0185077 \\
(0.145)\end{array}$ \\
\hline$O P N$ & & & & & & $\begin{array}{r}-.0010946 \\
(0.220)\end{array}$ \\
\hline d.ULC & & & & & $\begin{array}{r}.0081187 \\
(0.232)\end{array}$ & $\begin{array}{r}.0084806 \\
(0.203)\end{array}$ \\
\hline EUDUMMY & & $\begin{array}{r}.1572891 * \\
(0.072)\end{array}$ & $\begin{array}{r}.1976918^{* *} \\
(0.015)\end{array}$ & $\begin{array}{r}.1980934 * * \\
(0.014)\end{array}$ & $\begin{array}{r}.235527 * * * \\
(0.003)\end{array}$ & $\begin{array}{r}.2570031 * * * \\
(0.002)\end{array}$ \\
\hline$\alpha$ & $\begin{array}{r}.6790423 * * * \\
(0.001)\end{array}$ & $\begin{array}{r}.6784586 * * * * \\
(0.000)\end{array}$ & $\begin{array}{r}.5418985^{* * * *} \\
(0.004)\end{array}$ & $\begin{array}{r}.5472755^{* * * *} \\
(0.004)\end{array}$ & $\begin{array}{r}.5032021 * * \\
(0.011)\end{array}$ & $\begin{array}{r}.5716035 * * * \\
(0.004)\end{array}$ \\
\hline$\rho(A R(1)$ coefficient $)$ & .7901183 & .7764514 & .7430232 & .7388132 & . 6948972 & 6958169 \\
\hline$R^{2}$ & 0.0783 & 0.1053 & 0.1072 & 0.1346 & 0.1373 & 0,1478 \\
\hline$F$-test & $F(1,14)=$ & $F(1,14)=$ & $\mathrm{F}(1,14)=$ & $\mathrm{F}(1,14)=$ & $F(1,14)=$ & $\mathrm{F}(1,14)=$ \\
\hline & $\begin{array}{r}29.493 \\
(0.0001)\end{array}$ & $\begin{array}{r}29.618 \\
(0.0001)\end{array}$ & $\begin{array}{r}28.925 \\
(0.0001)\end{array}$ & $\begin{array}{r}30.982 \\
(0.0001)\end{array}$ & $\begin{array}{r}27.194 \\
(0.0001)\end{array}$ & $\begin{array}{r}28.388 \\
(0.0001)\end{array}$ \\
\hline$m$-Wald test & $x^{2}(15)=81.28$ & $x^{2}(15)=78.44$ & $x^{2}(15)=48.82$ & $x^{2}(15)=73.29$ & $x^{2}(15)=167.79$ & $x^{2}(15)=152.67$ \\
\hline & $(0.0000)$ & $(0.0000)$ & $(0.0000)$ & $(0.0000)$ & $(0.0000)$ & $(0.0000)$ \\
\hline
\end{tabular}

Notes: p-values in parentheses, $* * *, * *$ and $*$ indicate $10 \%, 5 \%$ and $1 \%$ statistical significance, respectively.

Table 4b. Pooled-OLS with Driscoll-Kraay Corrected Standard Errors.

\begin{tabular}{|c|c|c|c|c|c|c|}
\hline INFp & \multicolumn{2}{|c|}{ (4) } & \multicolumn{2}{|c|}{ (3) } & \multicolumn{2}{|c|}{ (2) } \\
\hline TRNS & $\begin{array}{l}-.040095 * * * \\
(0.003)\end{array}$ & $\begin{array}{l}-.049604 * * * \\
(0.000)\end{array}$ & $\begin{array}{l}-.0298163 * * \\
(0.012)\end{array}$ & $\begin{array}{l}-.0292843 * * \\
(0.013)\end{array}$ & $\begin{array}{l}-.023710^{* * * *} \\
(0.006)\end{array}$ & $\begin{array}{l}-.023938^{* * *} \\
(0.006)\end{array}$ \\
\hline$G D P g$ & & & & $\begin{array}{l}.0071711^{*} \\
(0.066)\end{array}$ & $\begin{array}{l}.0064678^{*} \\
(0.085)\end{array}$ & $\begin{array}{l}.0065914 * * * \\
(0.002)\end{array}$ \\
\hline$I R$ & & & $\begin{array}{l}.0326241 * \\
(0.059)\end{array}$ & $\begin{array}{l}.0316275^{*} \\
(0.061)\end{array}$ & $\begin{array}{l}.0428235^{* * * *} \\
(0.002)\end{array}$ & $\begin{array}{l}.0425187 * \\
(0.074)\end{array}$ \\
\hline$O P N$ & & & & & & $\begin{array}{l}-.0006129 \\
(0.465)\end{array}$ \\
\hline d.ULC & & & & & $\begin{array}{l}.0069803 \\
(0.488)\end{array}$ & $\begin{array}{l}.0073734 \\
(0.442)\end{array}$ \\
\hline EUDUMMY & & $\begin{array}{l}.1999105 * * * \\
(0.001)\end{array}$ & $\begin{array}{l}.2469986 * * * \\
(0.000)\end{array}$ & $\begin{array}{l}.2500727 * * * \\
(0.000)\end{array}$ & $\begin{array}{l}.2754309 * * * \\
(0.000)\end{array}$ & $\begin{array}{l}.2886835 * * * \\
(0.000)\end{array}$ \\
\hline$\alpha$ & $\begin{array}{l}.6991431 * * * \\
(0.000)\end{array}$ & $\begin{array}{l}.7359158 * * * \\
(0.000)\end{array}$ & $\begin{array}{l}.3854995 * * \\
(0.047)\end{array}$ & $\begin{array}{l}.3497699 * \\
(0.062)\end{array}$ & $\begin{array}{l}.2197829 * * \\
(0.033)\end{array}$ & $\begin{array}{l}.2636303 * \\
(0.051)\end{array}$ \\
\hline$R^{2}$ & 0.0721 & 0.1174 & 0.1812 & 0.1847 & 0.2174 & 0.2191 \\
\hline
\end{tabular}

Notes: p-values in parentheses, $* * *, * *$ and $*$ indicate $10 \%, 5 \%$ and $1 \%$ statistical significance, respectively

an autocorrelation issue and the modified Wald test show heteroskedasticity in the fixed effects regression model. Due to the heteroskedasticity and autocorrelation problems, we continue our methodology with an autoregressive (AR(1)) model, using Prais-Winsten Panel Corrected Standard Errors and a Pooled-OLS regression, using Driscoll and Kraay (1998) standard errors and results are shown, respectively, in Table $4 \mathrm{a}$ and $4 \mathrm{~b}$.

For our basic model, the results are highly statistically significant for transparency, unit labour cost and the EU dummy variable. The latter variables have a positive effect on inflation persistence, while transparency is reducing it. The negative relationship between central bank transparency and inflation persistence is justified on the ground that transparency is responsible for a better anchoring of inflation expectations affecting accordingly inflation persistence (Van der 
Cruijsen and Demertzis, 2007; Zhang, 2011). Our results come in line with Dincer and Eichengreen (2007), regarding the effects of the variables, although our results are more robust and also, we find a statistically significant effect of more variables, than the previous mentioned research.

In order to measure the robustness of our results, we focus on two stricter models, the first one without trade openness and first differences in unit labour cost and the second one using only transparency as the independent variable:

$$
\begin{gathered}
I N F p_{i t}=\alpha+\beta_{1} \text { TRNS }_{i t}+\beta_{2} I R_{i t}+\beta_{3} G D P g_{i t}+\beta_{4} E U D U M M Y_{i t}+\mu_{i}+u_{i t} \\
I N F p_{i t}=\alpha+\beta_{1} T R N S_{i t}+\mu_{i}+u_{i t}
\end{gathered}
$$

For the first regression, we find that transparency is statistically significant and has a negative impact on inflation persistence for all the panel data regressions employed. The same holds for the EU dummy variable, which has a positive impact on inflation persistence. GDP growth and money-market interest rates have a positive impact on inflation persistence in the Pooled-OLS regression. Openness and the unit labour costs have no effect on inflation persistence. Concerning central bank transparency, we confirm the negative effect on inflation persistence, as in Dincer and Eichengreen (2007) and Van der Cruijsen et Demertzis (2007). In effect, the public adjust their expectations more quickly under more transparent monetary policies, limiting policymakers' willingness to run accommodating policies in order to deal with increased output gaps. Regarding the EUDUMMY, the European Union countries share a common custom policy, however they have asymmetric structural characteristics. In this perspective, economic policy responses to shocks may be diffused with a different speed, resulting in different levels of inflation, enhancing inflation persistence. Concerning the relationship between inflation dynamics and money market rates we find a positive link, which is related to the so called "price puzzle" (Bernanke and Blinder 1992; Sims 1992). In effect, short-term interest rates affect borrowing rates and therefore the cost component to firms. It is not unlikely that the increased costs from higher interest rates precedes the contractionary effect on the demand side from higher rates, although it is not clear whether this is the case. The positive effect of GDP growth on inflation dynamics is reflected in the increase in the demand-side equation of the economy.

\section{Conclusion}

This paper contributes to the ongoing literature on the determinants of inflation persistence and the importance of highly transparent central banks. The existing literature has shown that transparency is a highly respectable characteristic of central banks with positive contributions to the economy. In our empirical framework, we consider 15 developed economies, with relatively low levels of inflation persistence and increasing levels of transparency. We include control variables widely used by the literature on inflation dynamics, which are not however extensively used in studies related to the relationship between central bank transparency and inflation persistence. Moreover, we expand the time period of the analysis with respect to previous studies. Our results confirm the negative link between central bank transparency and inflation persistence. It is to notice that interest rates have a positive impact on inflation persistence implying the occurrence of the price puzzle. The European Union dummy has a significant positive effect on inflation inertia, due to the different structural characteristics of the economies involved. In the case of the ECB, this result is emphasized by the fact that in a low interest rates environment and since the target of inflation was fulfilled, ECB's monetary policy had no incentive to increase its policy rates and risk missing its target.

Overall, the main policy implication of the paper is that there is a role of monetary policy characteristics on inflation persistence. Central banks dealing with inflation inertia might be in the difficult position to achieve poor results in terms of inflation stabilisation if their monetary 
policies are not transparent enough. This result holds even if the levels of inflation inertia are relatively low as it is the case for most of the developed countries.

\section{Acknowledgments}

We thank, the editor of Economics and Business Letters, Professor Francisco Delgado, and two anonymous reviewers for their comments, which substantially improved the quality of the paper. Any remaining errors are our own.

\section{References}

Alesina, A., and Summers, L. H. (1993) Central bank independence and macroeconomic performance: some comparative evidence, Journal of Money, Credit and Banking, 25(2), 151162.

Alogoskoufis, G. S. (1992) Monetary accommodation, exchange rate regimes and inflation persistence, The Economic Journal, 102(412), 461-480.

Alogoskoufis, G. (2018) The Clash of Central Bankers with Labour Market Insiders, and the Persistence of Inflation and Unemployment, Economica, 85(337), 152-176.

Andolfatto, D., and Gomme, P. (2003) Monetary policy regimes and beliefs, International Economic Review, 44(1), 1-30.

Ball, L. (1995) Time-consistent policy and persistent changes in inflation, Journal of Monetary Economics, 36(2), 329-350.

Batini, N. and E. Nelson (2001) The Lag from Monetary Policy Actions to Inflation: Friedman Revisited, International Finance, 4(3), 381-400.

Batini, N. (2002) Euro Area Inflation Persistence, ECB Working Paper No. 201.

Baxa, J., Plašil, M., and Vašíček, B. (2015) Changes in inflation dynamics under inflation targeting? Evidence from Central European countries, Economic Modelling, 44, 116-130.

Bernanke, B., and Blinder, A. S. (1992) The federal funds rate and the transmission of monetary policy, American Economic Review, 82(4), 901-21.

Blanchard, O., and Galí, J. (2007) Real wage rigidities and the New Keynesian model, Journal of Money, Credit and Banking, 39, 35-65.

Bratsiotis, G. J., Madsen, J., and Martin, C. (2015) Inflation targeting and inflation persistence, Economic and Political Studies, 3(1), 3-17.

Calvo, G. A. (1983) Staggered prices in a utility-maximizing framework, Journal of Monetary Economics, 12(3), 383-398.

Calvo, G. A., Celasun, O., and Kumhof, M. (2002) A theory of rational inflationary inertia, Knowledge, Information and Expectations in Modern Macroeconomics, in Honor of Edmund S. Phelps, 87-117.

Canarella, G., and Miller, S. M. (2016) Inflation persistence and structural breaks: The experience of inflation targeting countries and the USA, Journal of Economic Studies, 43(6), 9801005.

Christiano, L. J., Eichenbaum, M., and Evans, C. L. (2005) Nominal rigidities and the dynamic effects of a shock to monetary policy, Journal of Political Economy, 113(1), 1-45.

Conrad, C., and Eife, T. A. (2012) Explaining inflation-gap persistence by a time-varying Taylor rule, Journal of Macroeconomics, 34(2), 419-428.

Crowe, C. and Meade, E. E. (2007) The evolution of central bank governance around the world, Journal of Economic Perspectives, 21(4), 69-90.

Cukierman, A. (2002) Are contemporary central banks transparent about economic models and objectives and what difference does it make?, Federal Reserve Bank of St. Louis Review, 84(4), 15-36. 
de Mendonça, H. F., and de Siqueira Galveas, K. A. (2013) Transparency and inflation: What is the effect on the Brazilian economy?, Economic Systems, 37(1), 69-80.

Demertzis, M., and Hughes Hallett, A. H. (2007) Central bank transparency in theory and practice, Journal of Macroeconomics, 29(4), 760-789.

Diana, G., and Sidiropoulos, M. (2004) Central bank independence, speed of disinflation and the sacrifice ratio, Open Economies Review, 15(4), 385-402.

Dias, D. A., and Marques, C. R. (2010) Using mean reversion as a measure of persistence, Economic Modelling, 27(1), 262-273.

Dincer, N. N., and Eichengreen, B. (2007) Central bank transparency: where, why, and with what effects?, National Bureau of Economic Research, No. w13003.

Dincer, N. N., and Eichengreen, B. (2014) Central bank transparency and independence: Updates and New Measures, International Journal of Central Banking, 10(1), 189-259.

Driscoll, J. C., and Kraay, A. C. (1998) Consistent covariance matrix estimation with spatially dependent panel data, Review of Economics and Statistics, 80(4), 549-560.

Eijffinger, S. C., and Geraats, P. M. (2006) How transparent are central banks?, European Journal of Political Economy, 22(1), 1-21.

Eijffinger, S. C., Hoeberichts, M., and Schaling, E. (2000) Why money talks and wealth whispers: monetary uncertainty and mystique, Journal of Money, Credit and Banking, 32(2), 218235.

Erceg, C. J., and Levin, A. T. (2003) Imperfect credibility and inflation persistence, Journal of Monetary Economics, 50(4), 915-944.

Frees, E. W. (1995) Assessing cross-sectional correlation in panel data, Journal of Econometrics, 69(2), 393-414.

Fry, M., DeAnne, J., Mahadeva, L., Roger, S., and Sterne, G. (2000) Key issues in the choice of monetary policy framework, in Mahadeva, L. and Sterne, G., editors, Monetary policy frameworks in a global context, Routledge, London, 1-216.

Fuhrer, J., and Moore, G. (1995) Inflation persistence, The Quarterly Journal of Economics, 110(1), 127-159.

Fuhrer, J. C. (2010) Inflation persistence, in Handbook of monetary economics, Elsevier, 3, 423-486.

Geraats, P. M. (2005) Transparency and reputation: the publication of central bank forecasts, The B.E. Journal of Macroeconomics, 5(1), 1-28.

Geronikolaou, G., Spyromitros, E., and Tsintzos, P. (2016) Inflation persistence: The path of labor market structural reforms, Economic Modelling, 58, 317-322.

Geronikolaou, G., Spyromitros, E., and Tsintzos, P. (2019) Progressive taxation and human capital as determinants of inflation persistence, Economic Modelling, 88, 82-97.

Goodfriend, M., and King, R. G. (2001) The case for price stability, National Bureau of Economic Research, No. w8423.

Grüner, H. P. (2002) How much should central banks talk? A new argument, Economics Letters, 77(2), 195-198.

Hughes Hallett, A. and Libich, J. (2006) Central bank independence, accountability and transparency: complements or strategic substitutes? CEPR Discussion Papers, 5470, Centre for Economic Policy Research.

Huh, C. G., and Lansing, K. J. (2000) Expectations, credibility, and disinflation in a small macroeconomic model, Journal of Economics and Business, 52(1-2), 51-86.

Im, K. S., Pesaran, M. H., and Shin, Y. (2003) Testing for unit roots in heterogeneous panels, Journal of Econometrics, 115(1), 53-74.

Jaumotte, M. F., and Morsy, H. (2012) Determinants of inflation in the euro area: The role of labor and product market institutions, International Monetary Fund, No. 12-37. 
Kočenda, E., and Varga, B. (2018) The impact of monetary strategies on inflation persistence, International Journal of Central Banking, 14(4), 229-274.

Lane, P. R. (1997) Inflation in open economies, Journal of International Economics, 42(3-4), 327-347.

Levin, A., Lin, C. F., and Chu, C. S. J. (2002) Unit root tests in panel data: asymptotic and finite-sample properties, Journal of Econometrics, 108(1), 1-24.

Marques, C. R. (2004) Inflation persistence: Facts or artefacts (Vol. 371), European Central Bank.

Meller, B., and Nautz, D. (2012) Inflation persistence in the Euro area before and after the European Monetary Union, Economic Modelling, 29(4), 1170-1176.

Montes, G. C., and Gea, C. (2018) Central bank transparency, inflation targeting and monetary policy: a panel data approach, Journal of Economic Studies, 45(6), 1159-1174.

Noriega, A. E., Capistrán, C., and Ramos-Francia, M. (2013) On the dynamics of inflation persistence around the world, Empirical Economics, 44(3), 1243-1265.

Oikonomou, G., and Spyromitros, E. (2017) Trends in Central Bank Transparency, Theoretical Economics Letters, 7(7), 2089-2103.

Papadamou, S., and Arvanitis, V. (2015) The effect of the market-based monetary policy transparency index on inflation and output variability, International Review of Applied Economics, 29(1), 105-124.

Papadamou, S., Spyromitros, E., Tsintzos, P. (2017) Public investment, inflation persistence and central bank independence, Journal of Economic Studies, 44(6), 976-986.

Pesaran, M. H. (2004) General Diagnostic Tests for Cross Section Dependence in Panels, $C E$ Sifo Working Paper Series, No. 1229; IZA Discussion Paper No. 1240.

Qin, L., Sidiropoulos, M., and Spyromitros, E. (2013) Robust monetary policy under model uncertainty and inflation persistence, Economic Modelling, 30, 721-728.

Romer, D. (1993) Openness and inflation: theory and evidence, The Quarterly Journal of Economics, 108(4), 869-903.

Sibert, A. (2002) Monetary policy with uncertain central bank preferences, European Economic Review, 46(6):1093-1109.

Sims, C. A. (1992) Interpreting the macroeconomic time series facts: The effects of monetary policy, European Economic Review, 36(5), 975-1000.

Sørensen, J. R. (1991) Political uncertainty and macroeconomic performance, Economics Letters, 37(4), 377-381.

Stock, J. H. and Watson, M. W. (2007) Why has US inflation become harder to forecast?, Journal of Money, Credit and Banking, 39(1), 3-33.

Taylor, J. B. (1980) Aggregate dynamics and staggered contracts, Journal of Political Economy, 88(1), 1-23.

Taylor, J. B. (2000) Low inflation, pass-through, and the pricing power of firms, European Economic Review, 44(7), 1389-1408.

Van der Cruijsen, C., and Demertzis, M. (2007) The impact of central bank transparency on inflation expectations, European Journal of Political Economy, 23(1), 51-66.

Van der Cruijsen, C. A., Eijffinger, S. C., and Hoogduin, L. H. (2010) Optimal central bank transparency, Journal of International Money and Finance, 29(8), 1482-1507.

Weber, C. S. (2018) Central bank transparency and inflation (volatility) - new evidence, International Economics and Economic Policy, 15(1), 21-67.

Westelius, N.J. 2005) Discretionary monetary policy and inflation persistence, Journal of Monetary Economics, 52(2), 477-496.

Westelius, N. J. (2009) Imperfect transparency and shifts in the central bank's output gap target, Journal of Economic Dynamics and Control, 33(4), 985-996. 
Wooldridge, J. M. (2003) Further results on instrumental variables estimation of average treatment effects in the correlated random coefficient model, Economics Letters, 79(2), 185-191. Zhang, C. (2011) Inflation persistence, inflation expectations, and monetary policy in China, Economic Modelling, 28(1-2), 622-629. 